www.volsu.ru

DOI: https://doi.org/10.15688/nav.jvolsu.2021.1.4

UDC 902

LBC $63.4(2)$

Submitted: 20.07.2020

Accepted: 27.05 .2021

\title{
ABOUT WOMEN'S CLOTHING WITH DECORATED SLEEVES FROM THE FILIPPOVKA I KURGAN CEMETERY
}

\author{
Konstantin S. Okorokov \\ Institute of Archaeology of the Russian Academy of Sciences, Moscow, Russian Federation \\ Vyacheslav E. Tregubov \\ Orenburg Governor's Local History Museum, Orenburg, Russian Federation
}

\begin{abstract}
During the archaeological study of the Filippovka I kurgan cemetery, several burial complexes were revealed containing items related to women's clothing. The article analyzes the burials where these items were found intact - burial 2 of kurgan 1 and burial 4 of kurgan 4 . As a result of comparing the types of sewn-on elements and their positioning in the burial, a certain similarity between the complexes was found, so it's possible to draw a conclusion about the general appearance of the female clothing from the kurgan cemetery. In addition to the gold stripes made in the animal style, fragments of beaded embroidery decorating the sleeves of one of the clothing elements were found in burial 2 of kurgan 1. Protomes of deer marching in a row were depicted using regular and small beads of different materials on the sleeves. The article contains a description of the best preserved figures. Also, the first explorer of the cemetery A. Kh. Pshenichnyuk discovered in kurgan 1 a cache with a large number of gold patches on clothes as well as other items made of precious metals. Typological and stylistic similarity with patches from the burials examined allowed the authors of the article to make an assumption about the similarity between clothing from the cache and the burials. Specific features of the early Sarmatian animal style appear in the gold patches of clothing and the lining of wooden bowls from the Filippovka I kurgan cemetery. This allows us to assume that the entire set of implements with the Philippian animal style was made by order and matching the taste of the early nomads.

Key words: animal style, Filippovka I kurgan cemetery, clothing reconstruction, Southern Urals, earlynomads, gold stripes, decorated sleeves.

Citation. Okorokov K.S., Tregubov V.E., 2021. O predmetah zhenskoy odezhdy s dekorirovannymi rukavami iz mogil'nika Filippovka I [About Women's Clothing with Decorated Sleeves from the Filippovka I Kurgan Cemetery]. Nizhnevolzhskiy Arkheologicheskiy Vestnik [The Lower Volga Archaeological Bulletin], vol. 20, no. 1, pp. 51-68. DOI: https://doi.org/10.15688/nav.jvolsu.2021.1.4
\end{abstract}

УДК 902

Дата поступления статьи: 20.07.2020

ББК 63.4(2)

Дата принятия статьи: 27.05.2021

\section{О ПРЕДМЕТАХ ЖЕНСКОЙ ОДЕЖДЫ С ДЕКОРИРОВАННЫМИ РУКАВАМИ ИЗ МОГИЛЬНИКА ФИЛИППОВКА I}

\author{
Константин Сергеевич Окороков \\ Институт археологии РАН, г. Москва, Российская Федерация \\ Вячеслав Егорович Трегубов \\ Оренбургский губернаторский историко-краеведческий музей, г. Оренбург, Российская Федерация
}

Аннотация. В ходе археологического исследования курганного могильника Филипповка I было выявлено несколько погребальных комплексов с предметами, связанными с женскими костюмами. В статье анализируются погребения, в которых эти предметы обнаружены непотревоженными - погребение 2 кургана 1 и погребение 4 кургана 4. При сравнении типов нашивных элементов и их положения в погребении обнару- 
жились определенное сходство между комплексами, что позволило сделать вывод об общем облике женского костюма, представленного в могильнике. Помимо золотых нашивок, выполненных в зверином стиле, в погребении 2 кургана 1 выявлены фрагменты бисерной вышивки, которая декорировала рукава одного из элементов одежды. Посредством бисера и мелких бусин из разных материалов на рукавах были изображены протомы оленей, шествующих друг за другом. В статье приводится описание наиболее сохранившихся фигур. Также в кургане 1 первым исследователем могильника А.Х. Пшеничнюком был обнаружен тайник, где среди прочих предметов из драгоценных металлов находилось большое количество золотых нашивок на одежду. Обращает на себя внимание типологическая и стилистическая близость с нашивками из рассмотренных погребений, что позволило авторам статьи сделать предположение об аналогичности костюмов из тайника и погребений. В золотых нашивках одежды и обкладках деревянных чаш из курганного могильника Филипповка I проявляются специфические черты раннесарматского звериного стиля. Это позволяет предполагать о производстве на заказ соответственно вкусу ранних кочевников всего комплекса инвентаря с филипповским звериным стилем.

Ключевые слова: звериный стиль, курганный могильник Филипповка I, реконструкция костюма, Южное Приуралье, ранние кочевники, золотые нашивки, декорированные рукава.

Цитирование. Окороков К. С., Трегубов В. Е., 2021. О предметах женской одежды с декорированными рукавами из могильника Филипповка I// Нижневолжский археологический вестник. Т. 20, № 1. С. 51-68. DOI: https://doi.org/10.15688/nav.jvolsu.2021.1.4

Костюм традиционных обществ - сложная знаковая система, характеризующая не только конкретного человека, но и целый народ, представителем и выразителем культуры которого он является [Яценко, 2006, с. 5]. Вместе с тем плохая сохранность небольшого количества материалов, относящихся к костюму, является ощутимой преградой в исследовании этого вопроса в археологии ранних кочевников Южного Урала.

Археологический материал из некрополя Филипповка I, полученный в ходе раскопок 2006 и 2013 гг., позволяет обобщить и конкретизировать ряд наблюдений исследователей касательно реконструкции женской одежды ранних кочевников Южного Приуралья. В парном погребении 4 кургана 4 и женском погребении 2 кургана 1 могильника Филипповка I золотые нашивки, украшающие женский костюм, находились в непосредственной близости к костяку. Они известны и в других комплексах этого могильника, однако происходят из потревоженных грабителями или землеройными животными погребений. Отдельный и яркий случай - нахождение подобных нашивок в тайнике II в кургане 1 вместе с золотыми и серебряными сосудами, а также с деревянными фигурами оленей, оббитыми золотыми и серебряными листами. Ритуальные действия, в которых использовался данный набор предметов, проводились до сооружения насыпи кургана. Вероятно, артефакты, украшенные фигурами оленей, чаши со священным напит- ком [Переводчикова, 2016, с. 221; Федоров, 2006, с. 46-50] и женские одежды, украшенные золотыми нашивками, несли семантическую нагрузку в этих обрядовых действиях. Анализ предметов из погребения 4 кургана 4 и погребения 2 кургана 1 позволит предложить реконструкцию костюмов, уложенных в тайник II кургана 1 Филипповского I курганного могильника.

В 1987-1988 гг. археологической экспедицией ИИЯЛ БНЦ УрО АН СССР под руководством А.Х. Пшеничнюка проводилось первое исследование кургана 1. Было выявлено центральное погребение с дромосом, два тайника и подземные ходы, названные исследователем грабительскими лазами. Тайник II находился у западного края центрального погребения, в 6 м южнее тайника I, представляя собой прямоугольную яму размером $100 \times 50$ см и глубиной 90 см от уровня дневной поверхности [Пшеничнюк, 2012, с. 23]. В придонной части тайника II находилось четыре разновидности золотых нашивок - крупные, изображающие архаров и сражающихся верблюдов, и небольшие, изображающие лежащего оленя и протомы кошачьего хищника (рис. 1,1).

В 2004 г. работы на могильнике были возобновлены Приуральской экспедицией Института археологии РАН под руководством д.и.н. Л.Т. Яблонского. Исследованы все оставшиеся курганы Филипповского могильника, а также останец кургана 1. Интересую- 
щие нас памятники будут описаны в порядке их исследования.

В 2006 г. был исследован курган 4 [Яблонский, Мещеряков, 2007, с. 55-62]. Погребение 4 было расположено в восточной поле насыпи. Яма - неправильный четырехугольник $368 \times 417$ см глубиной 436 см от погребенной почвы с заплечиками со следами деревянного перекрытия вдоль широтных бортов. На дне погребения расчищено два скелета, лежавших вытянуто на спине, головой на юг. Лицо скелета 1 (мужского) обращено к скелету 2, который принадлежал девушке 18-20 лет (рис. 1,2). Погребенная лежала лицом вверх, руки вытянуты и прижаты к телу, ноги вытянуты, левая слегка согнута в колене. Вдоль обеих рук располагались 22 нашивки ${ }^{1}$ в виде изогнутых кошачьих хищников (рис. 2,5,6) размером $4 \times 2 \mathrm{~cm}$, направленных влево [Яблонский, 2008, с. 124-129]. По предположению Л.Т. Яблонского, эти нашивки являлись украшением бортов плаща: «...женщина была одета в плащ, борта которого украшены золотыми нашивками в виде фигур львов» [Яблонский, 2013, с. 19]. Несколько выше плечевых костей находились две крупные однотипные нашивки в виде протомы лежащего кошачьего хищника с расположенной фронтально полой головой, слегка опущенной на сложенные вместе лапы с длинными пальцами (рис. 2,3,4), а также 14 однотипных нашивок ${ }^{2}$ в виде лежащего кошачьего хищника с объемной полой головой (рис. 2,2). В ушах некоторых фигур остались следы вставок из голубой эмали, утраченных в древности. Их место руководитель раскопок определяет также «среди нашивок на плащ» [Яблонский, 2013, с. 98-99].

Анализ взаимного расположения определенно указывает на то, что нашивки двух типов принадлежат двум разным предметам одежды. Небольшие нашивки в виде изогнутых кошачьих хищников вероятнее всего являются украшением длинных узких рукавов платья - они расположены цепочкой вдоль костей обеих рук, примерно на одинаковом расстоянии друг от друга, от плеча до запястья.

Массивные нашивки с объемным изображением кошачьего хищника, судя по расположению, относятся ко второму предмету одежды, надетому поверх рубашки или платья с длинным узким рукавом. Интересно, что 7 фигур с правой руки ориентированы вправо, 7 фигур с левой руки ориентированы влево, две изображают животное в фас, при этом выполнены они по одной технологии. На непотревоженном участке у левой плечевой кости особенно отчетливо видно, что нашивки с протомой пантеры маркируют верхнюю линию плеча, чуть ниже нее по дуге полоса из семи пантер расположена так, что три пантеры оказываются на стороне спины, три - на стороне груди и одна - под нашивкой на плече. Концы этой ленты (каймы) не смыкаются. Таким образом, данный костюм состоит из двух деталей:

- платья с длинными узкими рукавами, украшенными с внешней стороны небольшими золотыми нашивками в виде изогнутого кошачьего хищника по всей длине руки;

- предмета одежды с широкими, но короткими, открытыми снизу рукавами, с украшающими кайму массивными объемными фигурами пантер, лежащих на боку (рис. 2,1, 7,4).

Кости мужского скелета лежат поверх нескольких нашивок с правого плеча женского скелета, поэтому можно предположить, что женщина была первой помещена в погребальную камеру (практически посередине), ее одежда была расправлена, а затем справа от нее было уложено тело мужчины.

В 2013 г. был доследован курган 1 [Яблонский, 2016, с. 744-766]. К востоку от центрального погребения, за пределами вала было обнаружено погребение 2 , ориентированное меридионально. Яма подпрямоугольной формы размером $520 \times 348 \mathrm{~cm}$, глубиной $436 \mathrm{~cm}$ от уровня погребенной почвы. На дне ямы, на органической подстилке растительного происхождения был расчищен женский скелет, лежащий головой на юг, лицом вверх. По определению руководителя раскопок, погребенной было около 35 лет [Яблонский, 2014, с. 24]. Помимо богатейшего сопроводительного инвентаря, в непосредственной близости от костяка, на нем и под ним находилось несколько сотен предметов, соотносимых с деталями одежды (рис. 1,3). Описанию этих предметов посвящено несколько работ Л.Т. Яблонского и О.В. Аникеевой, в которых детально рассмотрены типы нашивок, сопутствующие украшения, а также их вероятное про- 
исхождение [Аникеева, Яблонский, 2019а; Аникеева, Яблонский, 2019б].

Вдоль обеих рук с внешней стороны располагались 26 золотых нашивок с изображением сцены терзания кошачьим хищником копытного полорогого животного (рис. 3,2, 4,1, 4,3). На левой руке животные на нашивках ориентированы влево (12 шт.), на правой руке вправо (14 шт.). Положение этих нашивок аналогично положению схожих по размеру нашивок из погребения 4 кургана 4 и свидетельствует о наличии платья с длинными узкими рукавами. В данном случае обшлага рукавов были дополнительно украшены сложносоставными звеньями с подвесками [Аникеева, Яблонский, 2019б, с. 17-18]. К платью же относятся 4 нашивки на груди с изображением копытного животного (рис. 3,1 ).

К другому предмету одежды, самому верхнему, мы относим: все золотые нашивки-розетки (395 шт.); бахрому из 106 миниатюрных золотых нашивок с двумя отверстиями в бортиках и 107 золотых подвесок из двух спаянных полусфер с петлей с одной стороны и зернью - с другой; золотые навершия шнуров (16 шт.).

Положение бахромы (рис. 4,2,5), по-видимому, изначально обрамлявшей лицо, вместе с положением золотых наверший шнуровзавязок (рис. 4,4 ) относительно костяка позволяет предположить, что в ходе осуществления погребения лицо умершей, а также часть тела до середины грудины были закрыты шалью. В процессе перемещения шали ее край под левой ногой, погребенной соответственно, сместился вверх, подняв с собой и прикрепленные на ней нашивки.

К еще одному предмету одежды мы относим участки бисерной вышивки размером 40-45 × 18 см, расчищенные около обеих рук (рис. $5,1,2)$. Эти скопления бисера располагались под локтевыми суставами и за пределами костяка. Оба участка фиксируются от середины плечевой кости приблизительно до середины предплечья. Данные объекты являются сложенными пополам лентами, изображения на которых ограничены каймой из золотых трубочек-пронизок.

Вышивка выполнена бисером и мелкими бусинами из различных материалов, в том числе из золота. Золотые бусины имеют раз- личные формы: от почти круглых до биконических, частично практически цилиндрических, с выраженным пояском посередине, размером $\approx 3$ мм.

Правый рукав сохранился значительно лучше левого. Основные элементы вышивки на левом рукаве соответствуют таковым на правом рукаве [Яблонский, 2014, с. 57].

В ходе работы с этими объектами было установлено, что рукава расшиты протомами оленей, шествующих друг за другом (рис. 6,1-3). Олени изображены идущими вправо, как бы выходя из-за спины (на правом рукаве). Под длинной, с характерной горбинкой мордой каждого оленя изображена согнутая передняя нога с выделенным копытом и клочком шерсти над ним на задней стороне ноги. Пасти животных приоткрыты, переданы валиком из бусин, подобным валиком выделена бородка. Рога, занимающие треть изображения, состоят из 2-4 отростков, скрученных в спирали. Подтреугольное ухо противопоставлено морде и находится между рогами и спиной животного, глаз подтреугольной, почти полулунной формы, согнутой в колене передней ноге противопоставлен завиток со стороны спины животного.

Сохранность правого рукава такова, что фиксируются семь фигур оленей, которым мы условно даем номера I-VII для удобства описания. Всего же площадь участков бисерной вышивки позволяет предположить, что фигур на каждом рукаве было 10.

Абрисы фигур однотипные, отличаются очень незначительными деталями, обусловленными возможностями техники шитья. Отличия присутствуют в цветовом наборе бисера и бус, используемых для каждого оленя.

Фигура I вписана в прямоугольник высотой 68,5 мм, шириной 78,5 мм. Морда вытянута, шириной от 10 до 13 мм. Пасть обозначена более крупными цилиндрическими бусинами красноватого цвета. В носу выявлен дополнительный ряд из четырех золотых бусин, размером аналогичных остальным. Этот дополнительный ряд формирует «горбинку» морды.

Рога животного изображены крупными, до трети всей фигуры, с четырьмя спиральными отростками. Два крупных (шириной 20 мм) отростка находятся над мордой, па- 
раллельно ей. Два мелких (шириной 15 мм) отростка за затылком располагаются параллельно шее. Считая слева направо, первая и третья спирали (мелкая и крупная) выполнены из золотых бусин, вторая спираль - из бледно-розовых бусин (коралл?), четвертая - из сравнительно крупных бусин розового и желтоватого цветов цилиндрической формы.

Глаз полулунной формы (высота -4 мм, ширина -8 мм), состоит из двух или трех полуразрушенных бусин розового и голубого цветов. Форма глаза хорошо читается благодаря кайме из плотно подогнанных золотых бусин в один ряд.

Ухо подтреугольной формы состоит из плохо сохранившихся бледно-розовых бусин.

Борода подтреугольной формы обозначена рядом золотых бусин, окаймляющих плохо сохранившуюся бусину ярко-голубого цвета.

Нога состоит из двух рядов золотых бусин, плечо - из трех рядов. Копыто подтреугольной формы из двух рядов золотых бусин, у основания расширяется дополнительным рядом-вставкой. Копыто подогнуто почти на $90^{\circ}$ к ноге. Клочок шерсти над копытом на задней части ноги плохо различим.

2-видный завиток за спиной животного состоит из двух рядов плотно подогнанных друг к другу золотых бусин.

На правом рукаве над рогами фигуры I встречаются также участки, расшитые золотыми бусинами меньшего размера $(\approx 1,5 \times 2$ мм).

Фигура II. Сохранилась передняя часть фигуры и один отросток рога, закрученный спиралью, шириной 17 мм. Морда скорее треугольной формы, высотой 15 мм. Хорошо читается кайма из золотых бусин, изображающая валик губ животного, внутри пасти - бусины розового цвета. На месте ноздри, как и у фигуры I, отчетливо видны две белые бусины уплощенно-цилиндрической формы. Сохранилось основание отростка рога 4, отходящего от отростка 3 , выполненного из бусин светло-розового цвета. Размер бороды - $10 \times 9$ мм. Клочок шерсти на задней части копыта выделен полукруглой каймой из бусин. Копыто $(11 \times 23$ мм) и борода выполнены из темнокоричневых (пиритовых?) бусин прямоугольной формы.

Фигура III вписана в условный прямоугольник высотой 65 мм, шириной 80 мм. 3о- лотыми бусинами вышиты нога, клочок шерсти на задней части копыта $(7 \times 7$ мм $)$, лопатка (часть 2-видного завитка), кайма уха, кайма глаза $(11 \times 4$ мм), второй и третий отростки рогов. В копыто $(23 \times 10$ мм), колено, бороду $(12 \times 8$ мм), ухо (длина 15 мм), основания первого и четвертого отростков рогов вшиты темно-коричневые бусины прямоугольной формы. Белые бусины находятся внутри пасти животного, а также над его глазом. Копыто вышито розовыми бусинами. Целостность рисунка нарушена в районе рогов. Шея шириной 15 мм.

Фигура IV сохранилась частично. Отсутствуют морда с бородой, по меньшей мере один отросток рогов, нога с копытом и грудь. Отросток рога 1, вероятно, не поместился между ухом оленя IV и носом оленя III, от него сохранилось основание, однако сама спираль заменена подпрямоугольным участком из темно-коричневых бусин. Голова, шея, один из сохранившихся отростков рогов (шириной 20 мм) выполнены золотыми бусинами. Другой отросток рогов состоит из бусин розового и желтоватого цветов. Ухо длиной 15 мм, часть 2-видного завитка на задней части тела животного, основания рогов заполнены темно-коричневыми бусинами подпрямоугольной формы. Глаз $(10 \times 3$ мм) выполнен 5 белыми бусинами. В этой фигуре использованы более мелкие золотые бусины. Шея (ширина 12 мм) состоит из 6 параллельных рядов таких бусин.

Олени, фиксируемые на изнанке рукава. Сохранность участка очень плохая.

Фигура V. Сохранилась часть головы из цилиндрических бледно-розовых бусин. Глаз (ширина - 15 мм, высота - 4 мм) вытянутый, полулунной формы из 11 золотых бусин. Часть завитка за спиной оленя и отростки рогов состоят из золотых бусин.

Фигура VI. Шея, морда, часть рогов выполнены из золотых бусин.

Фигура VII. Заполнение глаза (12 × 4 мм), кайма уха (16 мм), нога с копытом, часть рогов, лопатка (завиток?) состоят из золотых бусин. Морда (длиной 37 мм) вышита бледно-розовыми бусинами прямоугольной формы.

Положение бусин и бисера, положение отверстий на бусинах, прочие детали и особенности данного предмета позволяют охарактеризовать его как пример односторонней 
криволинейной вышивки, выполненной строчным швом. Эта техника известна и популярна и в настоящее время - ее используют, чтобы подчеркнуть детали сюжета. Бисер или бусины ложатся изогнутыми линиями, повторяющими рисунок. Изображение получается не сплошное, а как бы прорисованное.

Вероятно, сначала рисунок был нанесен на ткань-основу с помощью какого-нибудь красителя, а затем поверх этого наброска были нашиты бусины, о чем говорит тщательность проработки и точность изображений. Представляется справедливым предположение, что данный предмет произведен мастером своего дела.

Каждая фигура при схожести деталей и общих контуров имеет отличия в цвете используемых бусин. Не ясно, является ли это художественным замыслом или имеет место ограниченность в расходных материалах.

Все фигуры обшиты дополнительным рядом из голубых бисерин, плотно подогнанных друг к другу (рис. 6,2). На первый взгляд кажется, что весь фон выполнен из голубого бисера. Голубым бисером и темно-коричневыми бусинами заполнен фон между мордой оленя III и ухом оленя IV. Треугольные участки фона между завитками рогов этих фигур и каймой рукава из золотых столбиков заполнены бусинами розового, голубого, белого цветов, а также темно-коричневыми бусинами прямоугольной формы.

Представляется возможным оценить приблизительное количество используемых в вышивке бусин и бисерин. Для этого были посчитаны бусины и бисерины в деталях фигуры I, поскольку она сохранилась лучше остальных. Для контура головы использованы 38 золотых бусин; заполнения морды - 14 золотых + 2 бусины розового цвета, обозначающие пасть; контура глаза - 10 золотых бусин; заполнения глаза $-\approx 4$ бусины; борода - контур из 8 золотых бусин вокруг двух бусин плохой сохранности; нога с копытом $-\approx 33$ бусины; 乙-видный завиток - $\approx 28$ бусин; порядка двух-трех десятков бусин в заполнении шеи и груди; рога: спираль 1-28 золотых бусин, спираль 2-45 бусин бледно-розового цвета, спираль 3-36 золотых бусин, спираль 4 - от 26 до свыше 30 розовых бусин ${ }^{3}$. Вся фигура обтянута каймой в один ряд из более сотни плотно подогнанных друг к другу голубых бисерин толщиной 1 мм, диаметром 2 мм.

Таким образом, для нанесения одной фигуры было необходимо более 400 бусин.

Учитывая, что площадь одной фигуры составляет одну десятую площади всего предмета, а также добавив несколько десятков бусин и бисерин фона, общее количество бусин можно оценить в 4500-5000, из которых $\approx 250$ приходится на кайму из бусин-столбиков $(6 \times 2,5$ мм), где золотые бусины чередуются с бусинами схожих пропорций из другого материала.

Вышивка на левом рукаве сохранилась хуже, перемещена большая часть бусин (рис. 5,1 ), однако ряд деталей уцелел, что позволяет говорить о том, что изображения на левом рукаве идентичны изображениям на правом. Кайма из золотых столбиков, перемежающаяся с бусинами из других материалов, проходит посередине объекта, разделяя фронтальную и изнаночную стороны. На изнаночной стороне в центре участка отчетливо различима фигура оленя, выполненная золотыми бусинами, с глазом и пастью из розовых бусин. Изображение обшито рядом из бисера голубого цвета. Фигура расположена зеркально аналогичным изображениям на изнаночной стороне правого рукава. Следовательно, фигуры на рукавах зеркально симметричны и как бы выходят из-за спины, встречаясь нос к носу на передней части костюма. Кроме этой фигуры различимы также детали других оленей - части морд, завитки рогов. Помимо перемещенного состояния большого количества бусин, на самом объекте находится больше предметов, чем на правом рукаве - восемь золотых наверший шнуров, пять золотых нашивок со сценой терзания, несколько нашивок-розетт.

Представленные комплексы из двух самых крупных курганов могильника Филипповка I обладают рядом сходных черт. В первую очередь это расположение нашивных элементов относительно костяков - в обоих случаях реконструируется декорированная лента, сложенная пополам, которая находится с внешней стороны плечевых костей (в кургане 1 ближе к локтевому суставу, в кургане 4 ближе к плечевому суставу). В обоих случаях эти ленты изогнуты дугой, расширяясь наружу. 
Нижняя, разомкнутая часть находится от тела дальше, чем верхняя (место сгиба пополам). Сходство обнаруживается в сюжете - вереница животных, выходящих из-за спины на лицевую сторону одежды зеркально симметрично друг другу. Общность сюжета еще более интересна тем, что рукава исполнены в разных техниках: в одном случае это пришивание массивных объемных нашивок, в другом - полихромная бисерная вышивка.

В том, что костюмы из этих двух погребений близки по типу, убеждает и факт наличия небольших золотых нашивок вдоль рук погребенных. Костюм из погребения 2 кургана 1 явно продуман лучше - помимо большего количества нашивок и деталей, изображенные животные на нашивках вдоль рук также зеркально симметричны, в отличие от небольших нашивок из кургана 4, где все изображения направлены влево.

Проанализировав два этих костюма, мы можем по-новому взглянуть на золотые нашивки из тайника II кургана 1 могильника Филипповка I. Перед нами 4 типа нашивок:

-20 нашивок размерами $8 \times 6$ см в виде фигур архаров в спокойной позе. Голова животного объемная, спаяна из двух половин. На оборотной стороне припаяно четыре петли для крепления. У 10 фигурок головы повернуты влево, у 10 - вправо;

- 29 рельефных нашивок с изображением сцены борьбы двух верблюдов размерами $5 \times 4$ см с проделанными по углам отверстиями для пришивания;

- 54 нашивки прямоугольной формы с изображением фигуры лежащего оленя с подогнутыми ногами, размерами $2,8 \times 2 \mathrm{~cm}$, с четырьмя петлями для пришивания. На 20 нашивках олень смотрит влево, на 34 вправо;

- 63 нашивки с изображением протомы кошачьего хищника размерами $2 \times 3$ см с двумя петлями для пришивания [Коллекции ... , 2018, c. 16].

Представленные нашивки делятся на две группы - большие и малые, параметры и стилистические решения которых близки нашивкам из рассмотренных выше погребений. Исходя из количества нашивок, их типов и конфигурации можно сделать вывод, что в тайнике II находилось два кос- тюма, с малыми нашивками вдоль узкого рукава нижнего платья и широким рукавом верхней плечевой одежды, украшенной каймой из крупных нашивок. Наше предположение подтверждается и тем, что объемные фигуры архаров выполнены в такой же технике, что и объемные фигуры пантер из кургана 4 (но без пастовых вставок). Небольших нашивок каждого типа оказывается несколько больше для одного платья, чем зафиксировано in situ в погребениях, что может говорить о нескольких одинаковых платьях, о более плотном пришивании, либо о пришивании нашивок в два ряда (или иным образом).

Таким образом, из двух самых крупных (и богатых) курганов могильника Филипповка I происходят четыре близких по типу женских костюма, отличающиеся индивидуальными особенностями исполнения (рис. 7,2-4).

Образы звериного стиля, представленного на нашивках и узорной вышивке подобны тем, какие мы видим в материалах кургана 1 могильника Филипповка I [Окороков, Переводчикова, 2020, с. 33], таких как золотые накладки на деревянные сосуды. Это сходство позволяет нам предполагать целенаправленное производство этих предметов специально для нужд данной группы кочевого населения в едином производственном центре [Трейстер, Яблонский, 2012, с. 157; Переводчикова, 2006, с. 37-38; Переводчикова, 2008, с. 64-72; Переводчикова, Таиров, 2010, с. 202]. В настоящее время мы не придерживаемся точки зрения о длительном бытовании рассмотренных элементов костюма, хотя и не исключаем такой возможности [Трейстер, Яблонский, 2012, с. 281; Окороков, Переводчикова, 2020, с. 33; Аникеева, Яблонский, 2019а, с. 21; Аникеева, Яблонский, 2019б, с. 22; Трейстер и др., 2010, с. 83].

Авторы ставили перед собой цель рассмотреть комплексы с элементами женской одежды из курганов 1 и 4, осознавая, что в погребениях прочих курганов могильника Филипповка I встречаются золотые нашивки, а также предметы, вероятнее всего являющиеся наконечниками скрепляющих одежды шнуров (осторожно публиковавшиеся ранее как «навершия») [Окороков, 2020б, с. 131, рис. 2,1-7]. Большое количество этих пред- 
K.S. Okorokov, V.E. Tregubov. About Women's Clothing from the Filippovka I Kurgan Cemetery

метов, происходящих в большинстве случаев из потревоженных по разным причинам комплексов, заслуживает рассмотрения их в отдельной работе. Тем не менее предварительное и поверхностное знакомство с ними вызывает ощущение чрезвычайного сходства с элементами рассматриваемых в статье костюмов.

\section{ПРИМЕЧАНИЯ}

${ }^{1}$ Хранение: Оренбург, ОРОМ, инв. № 1908319104, в каталоге 2013 г. описано 14 штук.

${ }^{2}$ Хранение: Оренбург, ОРОМ, инв. № 1906719080, в каталоге 2013 г. описано 10 штук.

${ }^{3}$ Некоторые значения являются приблизительными из-за плохой сохранности части бусин и состояния вышивки в целом. 


\section{ИЛЛЮСТРАЦИИ}
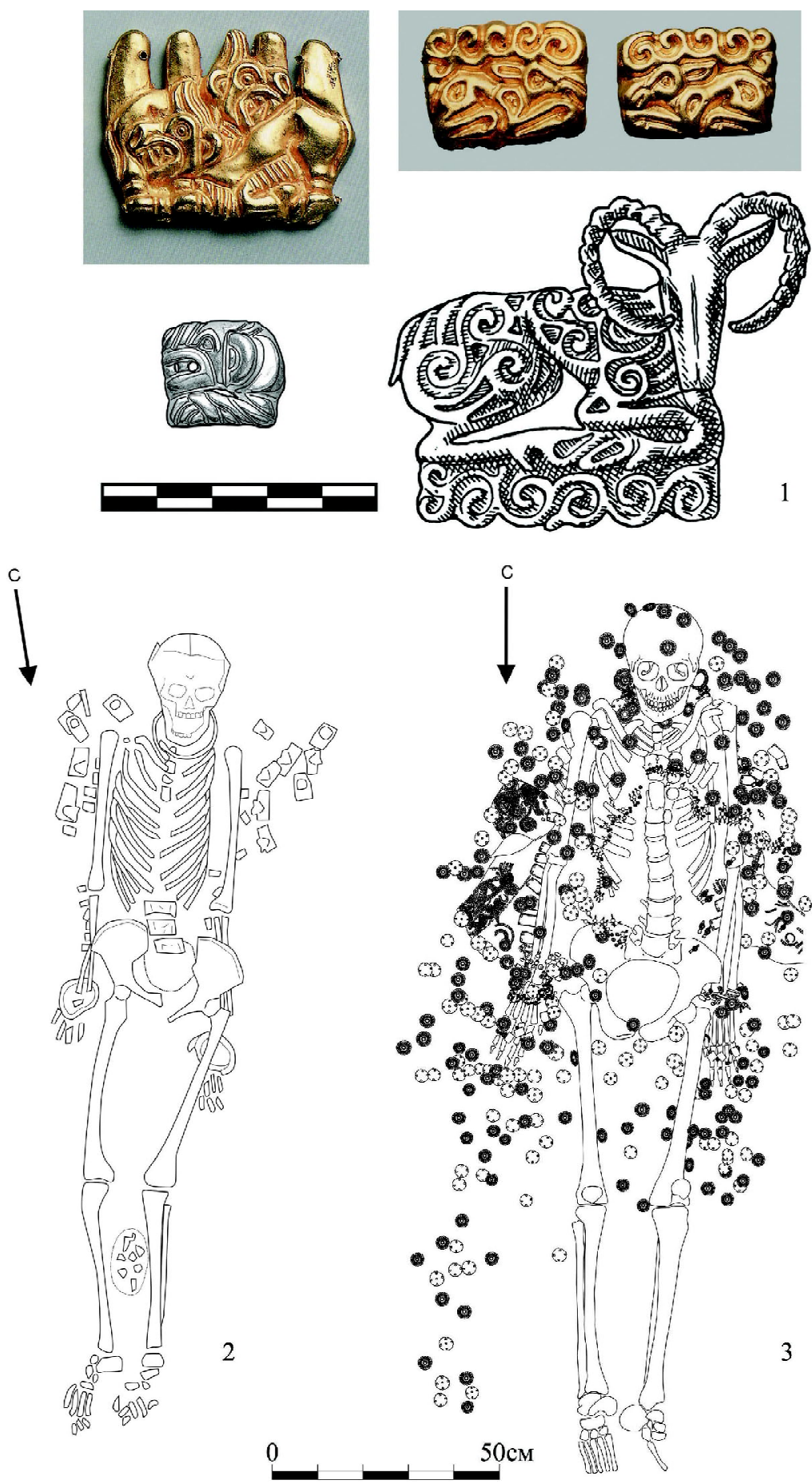

Рис. 1. Нашивные элементы декора костюмов из непотревоженных комплексов могильника Филипповка I:

1 - Филипповка I, курган 1, тайник 2, нашивки из придонной части (по: [Пшеничнюк, 2012, с. 111, рис. 24, фото 13-14]); 2 - Филипповка I, курган 4, погребение 4, положение нашивок на костяке (по: [Окороков, 2020, с. 202, рис. 2,1]); 3 - Филипповка I, курган 1, погребение 2, положение нашивок на костяке (по: [Окороков, 2020, с. 202, рис. 2,3])

Fig. 1. Patch elements of costume décor from undisturbed complexes of the Filippovka I kurgan cemetery: 1 - Filippovka I, kurgan 1, cache 2, stripes from the bottom part (after: [Pshenichnyuk, 2012, p. 111, fig. 24, photo 13-14]); 2 - Filippovka I, kurgan 4, burial 4, the position of the stripes on the skeleton (after: [Okorokov, 2020, p. 202, fig. 2,1]); 3 - Filippovka I, kurgan 1, burial 2, the position of the stripes on the skeleton (after: [Okorokov, 2020, p. 202, fig. 2,3]) 

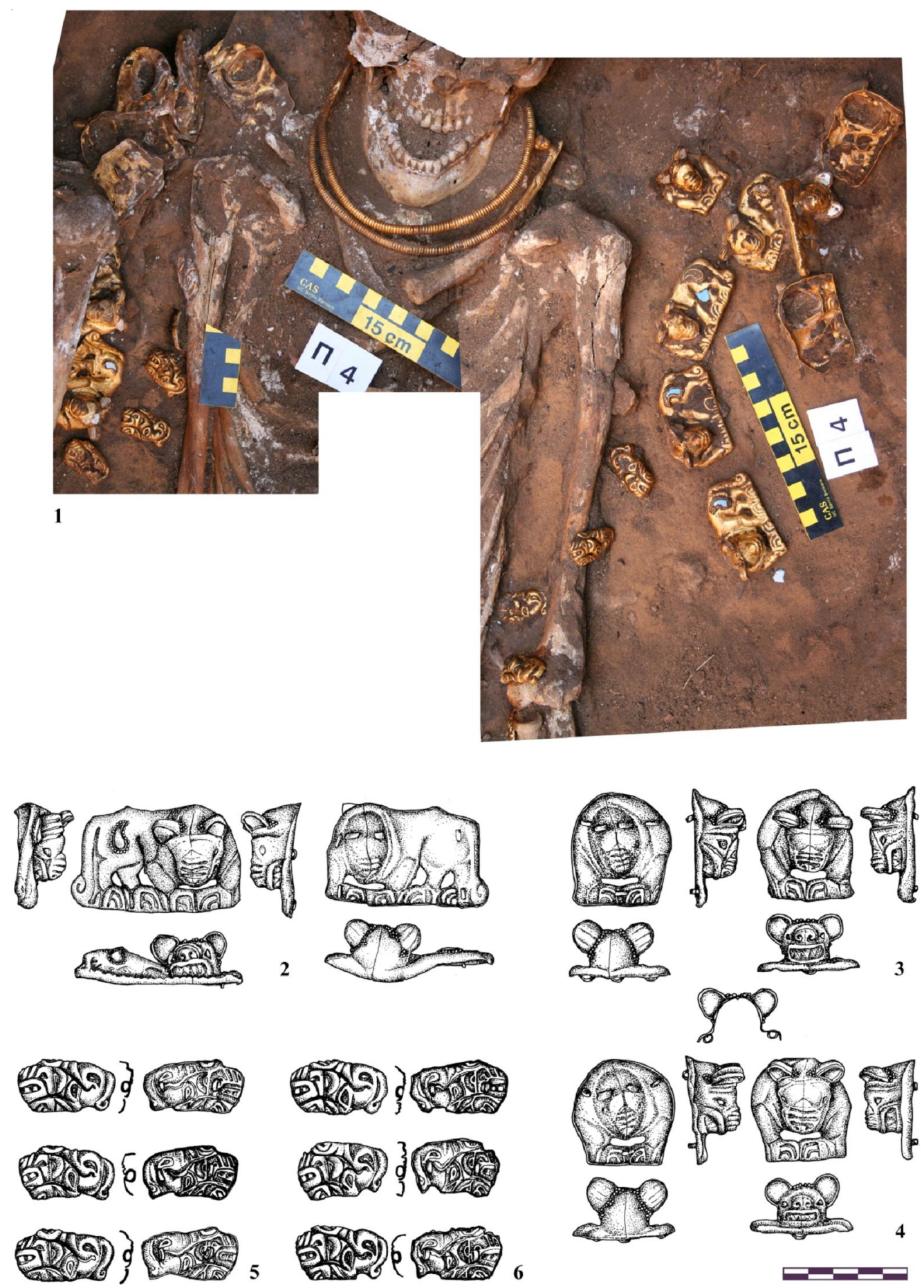

Рис. 2. Филипповка I, курган 4, погребение 4:

1 - положение нашивок на костяке (по: [Окороков, 2020, с. 201, рис. 1,4]);

2 - золотая нашивка № 61 (здесь и далее номера указаны по полевой описи); 3 - золотая нашивка № 63; 4 - золотая нашивка № $6 ; 5$ - золотые нашивки № 23, 24, 25; 6 - золотые нашивки № 56, 57, 58 (прорисовка И.В. Рукавишниковой)

Fig. 2. Filippovka I, kurgan 4, burial 4:

1 - the position of the patches at the skeleton (after: [Okorokov, 2020, p. 201, fig. 1,4]); 2 - gold patch No. 61 (here and below the numbers are listed according to the field inventory); 3 - gold patch No. 63; 4 - gold stripe No. 6; 5 - gold stripes No. 23, 24, 25; 6 - gold stripes No. 56, 57, 58 (trace drawing by I.V. Rukavishnikova) 
К.С. Окороков, В.E. Трегубов. О предметах женской одежды из могильника Филипповка I
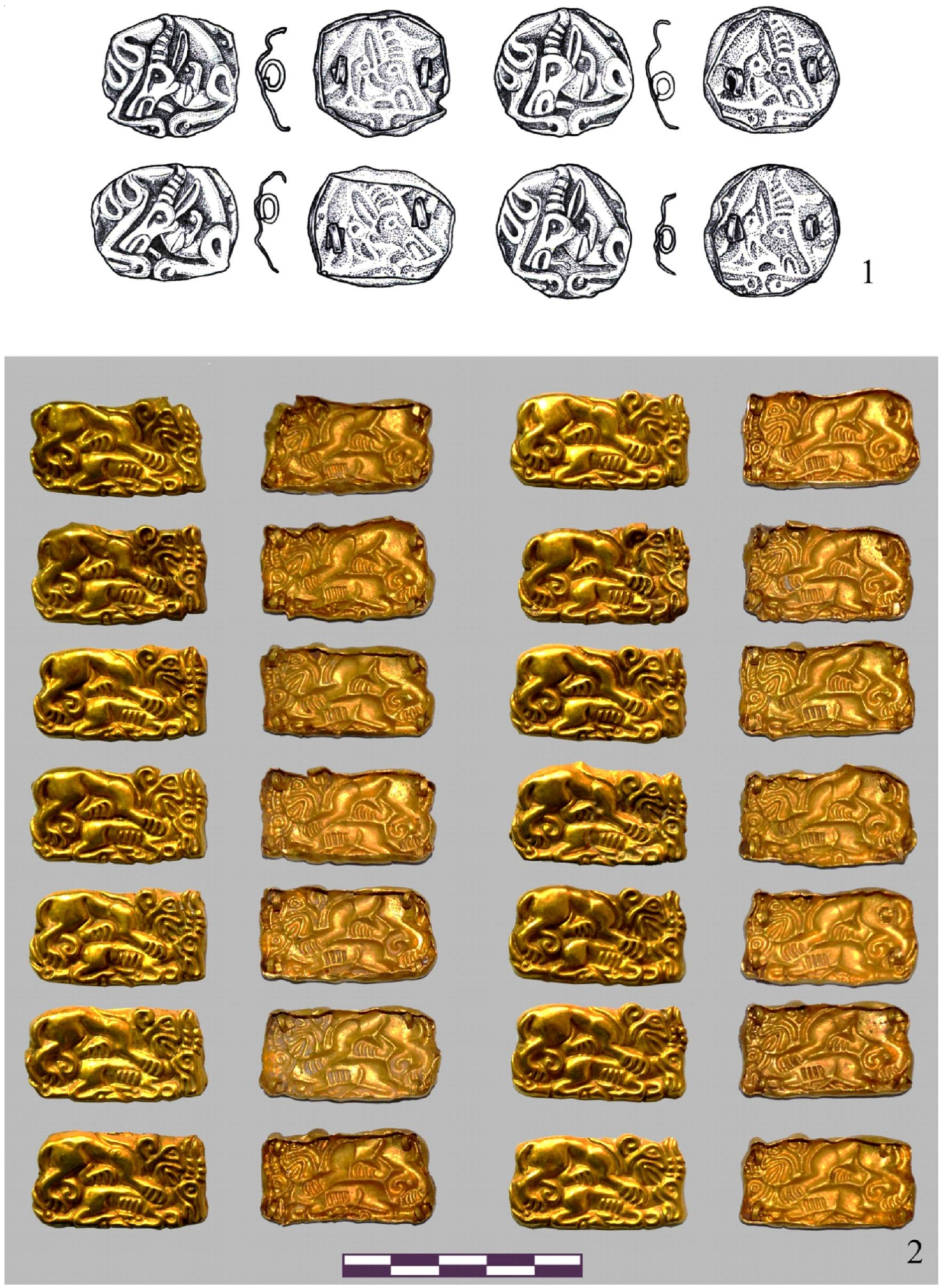

Рис. 3. Филипповка I, курган 1, погребение 2:

1 - золотые нашивки на груди (по: [Яблонский, 2014, с. 147, рис. 180,1-4]);

2 - золотые нашивки с правого рукава платья

Fig. 3. Filippovka I, kurgan 1, burial 2:

1 - gold patches on the chest (after: [Yablonskiy, 2014, p. 147, fig. 180,1-4]);

2 - gold stripes from the right sleeve of the dress 
K.S. Okorokov, V.E. Tregubov. About Women's Clothing from the Filippovka I Kurgan Cemetery
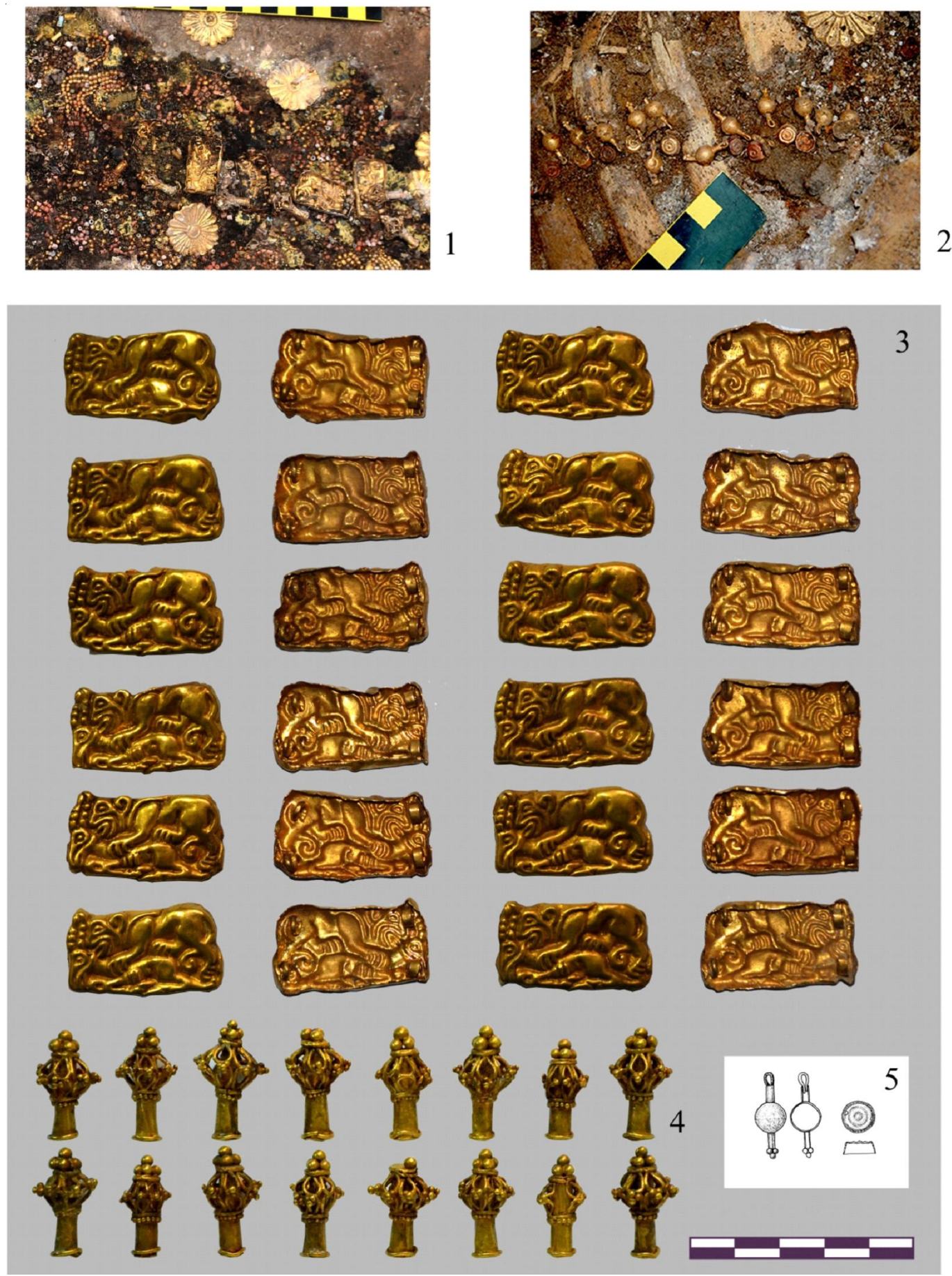

Рис. 4. Филипповка I, курган 1, погребение 2:

1 - положение нашивок левого рукава платья на участке бисерной вышивки (фрагмент);

2 - положение бахромы накидки (фрагмент) (по: [Яблонский, 2014, с. 148, рис. 182]);

3 - золотые нашивки с левого рукава платья; 4 - золотые навершия шнуров;

5 - элементы бахромы накидки (по: [Яблонский, 2014, с. 147, рис. 180,8-9])

Fig. 4. Filippovka I, kurgan 1, burial 2:

1 - the position of the patches on the left sleeve of the dress in the section of beaded embroidery (fragment);

2 - position of the cape fringe (fragment) (after: [Yablonskiy, 2014, p. 148, fig. 182]);

3 - gold stripes from the left sleeve of the dress; 4 - gold tops of cords;

5 - elements of the cape fringe (after: [Yablonskiy, 2014, p. 147, fig. 180,8-9]) 

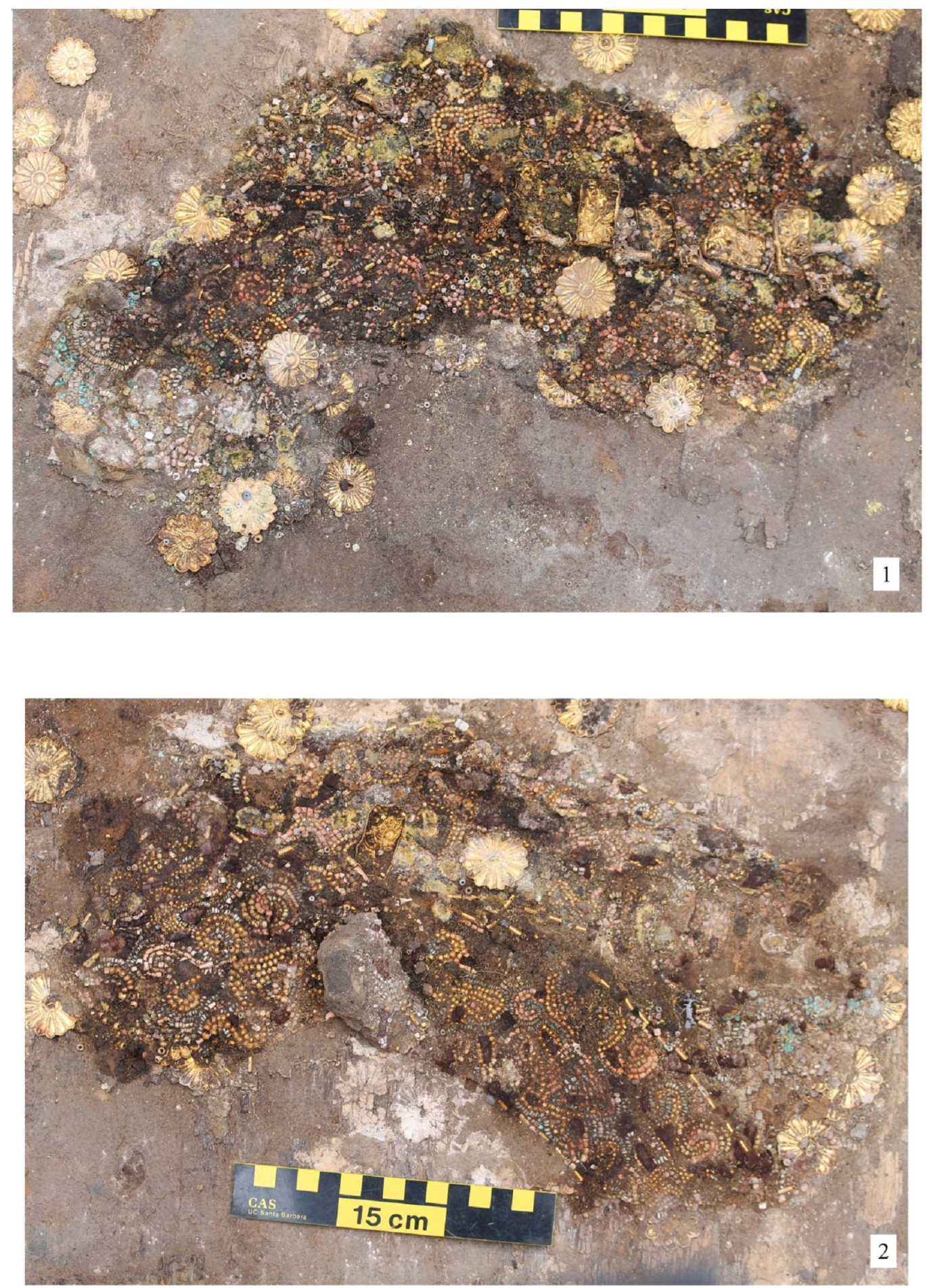

Рис. 5. Филипповка I, курган 1, погребение 2:

1 - участок бисерной вышивки слева от костяка, вид с запада;

2 - участок бисерной вышивки справа от костяка, вид с востока

Fig. 5. Filippovka I, kurgan 1, burial 2:

1 - section of beaded embroidery to the left of the skeleton, view from the west;

2 - section of beaded embroidery to the right of the skeleton, view from the east 


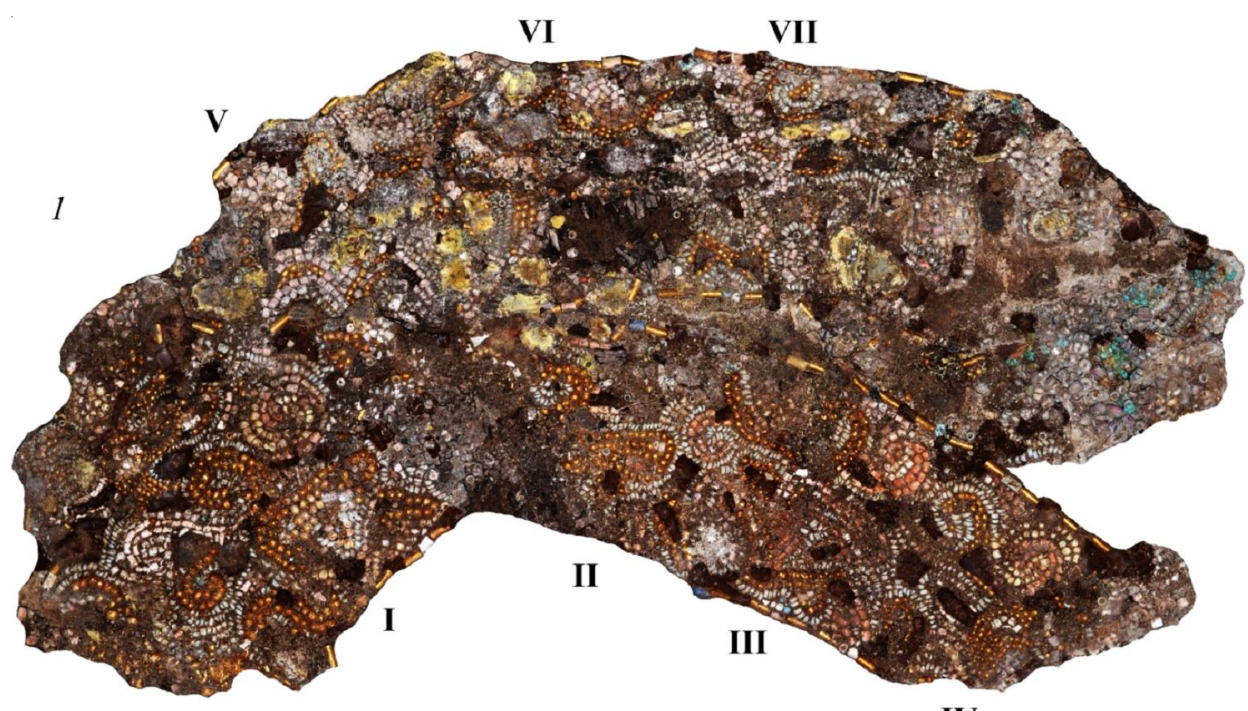

IV
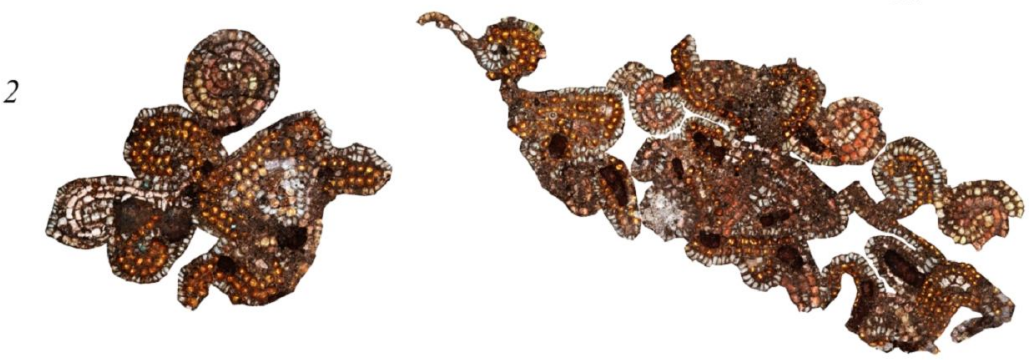

3
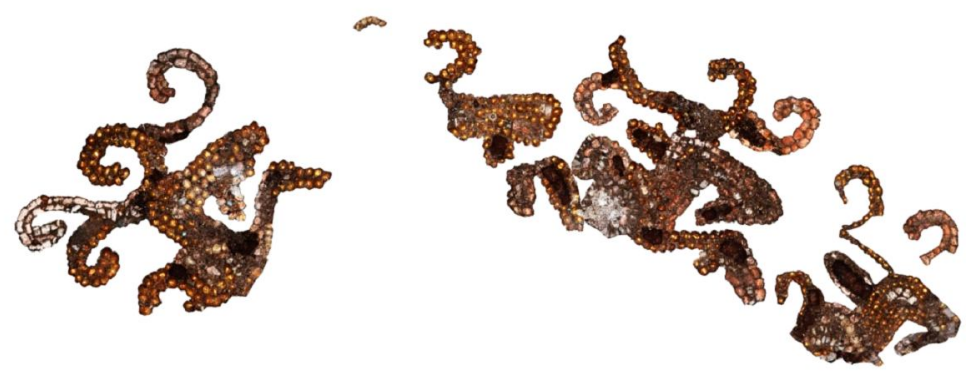

Рис. 6. Филипповка I, курган 1, погребение 2:

1 - участок бисерной вышивки справа от костяка с обозначением выявленных фигур оленей (фотография); 2 - наиболее сохранившиеся фигуры оленей с каймой из голубого бисера; 3 - те же фигуры оленей без каймы

Fig. 6. Filippovka I, kurgan 1, burial 2:

1 - section of beaded embroidery to the right of the skeleton with the designation of the identified figures of deer (photo); 2 - the best preserved figures of deer with a border of blue beads; 3 - the same figures of deer without a border 

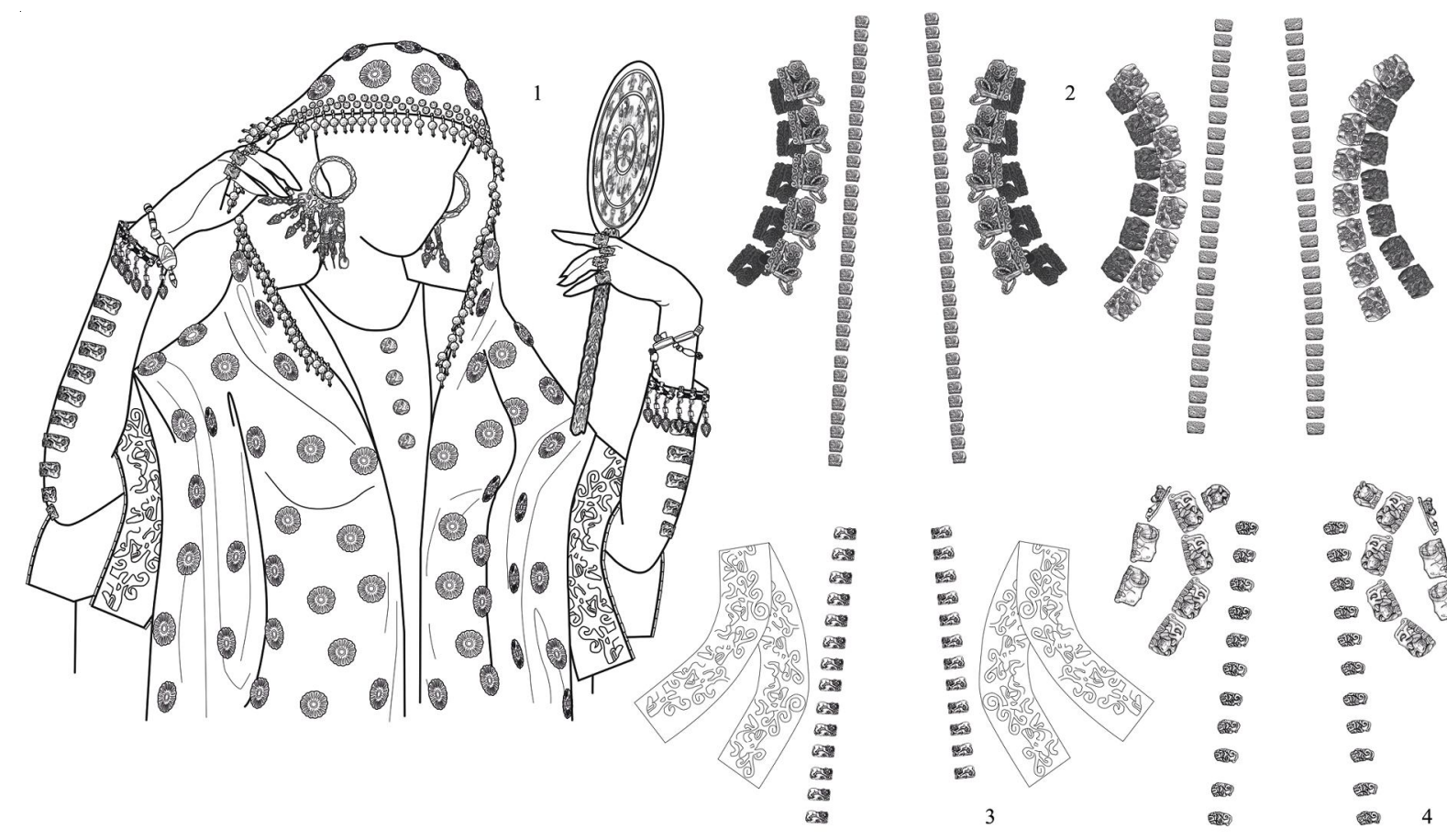

Рис. 7. Филипповка I:

1 - курган 1, погребение 2, графическая реконструкция костюма (по: [Окороков, 2020а, с. 202, рис. 3,2]);

2 - курган 1, тайник 2, реконструируемая схема декоративных элементов костюмов;

3 - курган 1, погребение 2, схема декоративных элементов костюмов;

4 - курган 4, погребение 4, схема декоративных элементов костюмов

Fig. 7. Filippovka I:

1 - kurgan 1, burial 2, graphic reconstruction of the costume (after: [Okorokov, 2020a, p. 202, fig. 3,2]);

2 - kurgan 1, cache 2 , reconstructed scheme of clothing decorative fixtures;

3 - kurgan 1, burial 2, scheme of clothing decorative fixtures;

4 - kurgan 4, burial 4 , scheme of clothing decorative fixtures 


\section{СПИСОК ЛИТЕРАТУРЫ}

Аникеева О. В., Яблонский Л. Т., 2019а. Материалы к реконструкции женского погребального костюма из элитного захоронения ранних кочевников Южного Приуралья // Крым в сарматскую эпоху (ІІ в. до н.э.IV в. н.э.) : материалы X Междунар. науч. конф. «Проблемы сарматской археологии и истории». Симферополь : Салта ЛТД. С. 14-24.

Аникеева О. В., Яблонский Л. Т., 2019б. Элементы погребального костюма жрицы из филипповских курганов: материалы к реконструкции // Археология евразийских степей. № 1. С. 12-32.

Коллекции Филипповских курганов из фондов Музея археологии и этнографии ИЭИ УФИЦ РАН : каталог, 2018. Уфа: Китап. 400 с.

Окороков К. С., Переводчикова Е. В., 2020. Находки 2013 г. в контексте звериного стиля кургана 1 курганного могильника Филипповка 1 // Нижневолжский археологический вестник. Т. 19, № 1. С. 28-45. DOI: https://doi.org/10.15688/nav.jvolsu.2020.1.2.

Окороков К. С., 2020а. Расшитые бисером рукава женского костюма из погребения 2 кургана 1 некрополя Филипповка I // Ранние кочевники Южного Урала и Нижнего Поволжья : материалы круглого стола «Археология ранних кочевников евразийской степи : актуальные проблемы и перспективы их решения». М. : ИА РАН. С. 189-202.

Окороков К. С., 2020б. Элементы костюма в погребальных комплексах Южного Урала // Волго-Уральский регион от древности до средневековья : материалы VI Нижневолж. Междунар. археол. науч. конф. Волгоград : Изд-во ВолГУ. С. 126-132.

Переводчикова Е. В., 2006. О цвете золота на оковках деревянных сосудов из 1 Филипповского кургана // Город и степь в контактной евро-азиатской зоне : III Междунар. конф., посвящ. 75-летию со дня рождения Г.А. Федорова-Давыдова (1931-2000) : тез. докл. М. : Нумизматическая литература. C. $37-28$.

Переводчикова Е. В., 2008. Золотые оковки сосудов из I Филипповского кургана: к постановке вопроса о месте производства // Ювелірне мистецтво - погляд крізь віки. Музейні читання : матеріали наукової конференції (12-14 листопада 2007). Київ : Фенікс. С. 64-72.

Переводчикова Е. В., Таиров А. Д., 2010. Произведения звериного стиля из 1-го Филипповского кургана в контексте искусства кочевников Южного Урала // Нижневолжский археологический вестник. Вып. 11. C. $198-212$.

Переводчикова Е. В., 2016. О стилистическом единстве произведений звериного стиля из 1-го Филипповского кургана // Урал-Алтай : через века в будущее : материалы VII Bсерос. тюркол. конф. (с междунар. участием), посвящ. 95-летию видного ученого-тюрколога Э.Р. Тенишева. Уфа : ИИЯЛ УНЦ РАН. C. $220-222$.

Пшеничнюк А. Х., 2012. Филипповка. Некрополь кочевой знати IV в. до н. э. на Южном Урале. Уфа : ИИЯЛИ УНЦРАН. $280 \mathrm{c}$.

Трейстер М. Ю., Яблонский Л. Т., 2012. Влияния ахеменидской культуры в Южном Приуралье (V-III вв. до н.э.) : в 2 т. Т. І. М. : ТАУС. 671 с.

Трейстер М. Ю., Шемаханская М. С., Яблонский Л. Т., 2010. Ахеменидская (?) серебряная рукоять ножа в форме фигуры оленя из Филипповки // Российская археология. № 3. С. 73-85.

Федоров В. К., 2006. О предназначении деревянных сосудов ранних кочевников Южного Урала, украшенных драгоценными обкладками // Южный Урал и сопредельные территории в скифо-сарматское время : сб. ст. к 70-летию А.Х. Пшеничнюка. Уфа : Гилем. С. 46-57.

Яблонский Л. Т., Мещеряков Д. В., 2007. Раскопки «царского» кургана в Филипповке (предварительное сообщение) // Российская археология. № 2. С. 55-62.

Яблонский Л. Т., 2008. Отчет о раскопках кургана 4 могильника Филипповка 1 на территории Илекского района Оренбургской обл. РФ в 2006 г. // Архив ИА РАН. Ф-1. Р-1. № 44152. № 44153. Альбом иллюстраций к отчету.

Яблонский Л. Т., 2013. Золото сарматских вождей. Элитный некрополь Филипповка 1 (по материалам раскопок $2004-2009$ гг.) : кат. кол. Кн. 1. М. : ИА РАН. 232 с.

Яблонский Л. Т., 2014. Отчет о доследовании кургана 1 могильника Филипповка 1 в 2013 г. // Архив ИА РАН. Ф-1. Р-1. № 41778. № 41779. Альбом иллюстраций к отчету. 
Яблонский Л. Т., 2016. Новые археологические данные об ахеменидских влияниях на Южном Урале // Вестник древней истории. № 3 (76). С. 744-766.

Яценко С. А., 2006. Костюм древней Евразии : ираноязычные народы. М. : Восточная литература. 664 c.

\section{REFERENCES}

Anikeeva O.V., Yablonsky L.T., 2019a. Materialy k rekonstruktsii zhenskogo pogrebal'nogo kostyuma iz elitnogozahoroneniya rannih kochevnikov Yuzhnogo Priural'ya [Materials for the Reconstruction of the Female Funeral Costume from the Elite Burial of of Southern Ural Early Nomads]. Krym v sarmatskuyu epohu (II v. do n.e. $-I V$ v. n.e.): materialy X Mezhdunar. nauch. konf. «Problemy sarmatskoy arheologii i istorii»» [The Crimea in the Age of the Sarmatians (200 BC-AD 400). Proceedings of the $10^{\text {th }}$ International Research Conference "The Aspects of Sarmatian Archaeology and History"]. Simferopol', Salta LTD Publ., pp. 14-24.

Anikeeva O.V., Yablonskiy L.T., 20196. Elementy pogrebal'nogo kostyuma zhricy iz filippovskih kurganov: materialy k rekonstruktsii [Elements of Priestess Funeral Dress from Filippovka I Burial Ground: Materials to Reconstruction]. Arheologiya evraziiyskih stepey [Archaeology of the Eurasian Steppe], no. 1, pp. 12-32.

Kollektsii Filippovskih kurganov iz fondov Muzeya arheologii i etnografii IEI UFIC RAN: catalog, 2018 [The Filippovka Barrows Collections in the Museum of Archaeology and Ethnology of Institute of Ethnological Studies UFC RAS: Catalog]. Ufa, Kitap Publ. 400 p.

Okorokov K.S., Perevodchikova E.V., 2020. Nahodki 2013 g. v kontekste zverinogo stilya kurgana 1 kurgannogo mogil'nika Filippovka 1 [The 2013 Finds in the Context of the Animal Style of the Kurgan 1 of the Necropolis Filippovka 1]. Nizhnevolzhskiy Arkheologicheskiy Vestnik [The Lower Volga Archaeological Bulletin], vol. 19, no. 1, pp. 28-45. DOI: https://doi.org/10.15688/nav.jvolsu.2020.1.2

Okorokov K.S. 2020a. Rasshitye biserom rukava zhenskogo kostyuma iz pogrebeniya 2 kurgana 1 nekropolya Filippovka I [Beaded Sleeves of a Female Costume from Burial 2 of Mound 1 of the Necropolis Filippovka I]. Rannie kochevniki Yuzhnogo Urala i Nizhnego Povolzh'ya. Materialy kruglogo stola «Arheologiya rannih kochevnikov evraziyskoy stepi: aktual'nye problemy i perspektivy ih resheniya» [Early Nomads of the Southern Urals and the Lower Volga Region. Materials of the Round Table Conference "Archaeology of the Early Nomads of the Eurasian Steppe: Current Problems and Prospects for Their Solution"]. Moscow, IA RAS, pp. 189-202.

Okorokov K.S. 2020б. Elementy kostuma v pogrebal'nyh kompleksah Yuzhnogo Urala [Costume Elements in the Burial Complexes of the Southern Urals]. Volgo-Ural'skiy region ot drevnosti do srednevekov'ya: materialy VI Nizhnevolzhskoy Mezhdunarodnoy arheologicheskoy nauchnoy konferentsii [Volga-Ural Region from Antiquity to the Middle Ages: Materials of the VI Lower Volga International Archaeological Scientific Conference]. Volgograd, VolSU, pp. 126-132.

Perevodchikova E.V., 2006. O tsvete zolota na okovkah derevyannyh sosudov iz 1 Filippovskogo kurgana [About the Color of Gold on the Fittings of Wooden Vessels from 1 Filippovskiy Kurgan]. Gorod i step'v kontaktnoy evro-aziatskoy zone. III Mezhdunarodnaya konferentsiya, posvyashchennaya 75-letiyu so dnya rozhdeniya G.A. Fedorova-Davydova (1931-2000). Tezisy dokladov [City and Steppe in the Contact Euro-Asian Zone. III International Conference Dedicated to the $75^{\text {th }}$ Anniversary of the Birth of G.A. Fedorov-Davydov (19312000). Abstracts of Reports]. Moscow, Numizmaticheskaya literatura Publ., pp. 37-28.

Perevodchikova E.V., 2008. Zolotye okovki sosudov iz I Filippovskogo kurgana: k postanovke voprosa o meste proizvodstva [Golden Fetters of Vessels from the I Filippovka Kurgan: to the Question of the Place of Production]. Yuvelirne mystettstvo - pohlyad kriz viki. Muzeyni chytanyya. Materyali naukovoi konferentsii (12-14 lystopada 2007) [The Art of Jewellery - Look Through the Ages. Museum Reading. Materials of the Scientific Conferences (November 12-14, 2007)]. Kiev, Fenix Publ., pp. 64-72.

Perevodchikova E.V., Tairov A.D., 2010. Proizvedeniya zverinogo stilya iz 1-go Filippovskogo kurgana v kontekste iskusstva kochevnikov Yuzhnogo Urala [Pieces of Scythian Animal Style Art from Filippovsky I Kurgan in the Context of the Southern Urals Nomadic Art]. Nizhnevolzhskiy Arkheologicheskiy Vestnik [The Lower Volga Archaeological Bulletin], iss. 11, pp. 198-212.

Perevodchikova E.V., 2016. O stilisticheskom edinstve proizvedeniy zverinogo stilya iz 1-go Filippovskogo kurgana [On the Stylistic Unity of the Animal Style from the 1 Filippovka Kurgan]. Ural-Altay: cherez veka v budushchee. Materialy VII Vserossiyskoy tyurkologicheskoy konferentsii (s mezhdunarodnym uchastiem), posvyashchennoy 95-letiyu vidnogo uchenogo-tyurkologa E.R. Tenisheva [Ural-Altay: Cross the Ages 
to the Future. Proceedings of the All-Russian Turcological Conference (with International Members) to the $95^{\text {th }}$ Anniversary of the Outstanding Turcologist E.R. Tenishev]. Ufa, IHLL USC RAS, pp. 220-222.

Pshenichnyuk A.H., 2012. Filippovka. Nekropol' kochevoy znati IV v. do n.e. na Yuzhnom Urale [Filippovka. Nekropolis of the Nomad Nobility (4 $4^{\text {th }}$ BC in the South Urals)]. Ufa, IHLL USC RAS. 280 p.

Treister M.Yu., Yablonskiy L.T., 2012. Vliyaniya akhemenidskoy cul'tury v Yuzhnom Priural'e (V-III vv. do n.e.) [Influences of the Achaemenid Culture in the Southern Urals (V-III Centuries BC)]. Vol. I. Moscow, TAUS Publ. $671 \mathrm{p}$.

Treister M.Yu., Shemahanskaya M.S., Yablonskiy L.T., 2010. Ahemenidskaya (?) serebryanaya rukoyat' nozha v forme figury olenya iz Filippovki [Deer-shaped Achaemenid (?) Silver Knife Handle from Filippovka]. Rossiyskaya arkheologiya [Russian Archaeology], no. 3, pp. 73-85.

Fyodorov V.K., 2006. O prednaznachenii derevyanny sosudov rannih kochevnikov Yuzhnogo Urala, ukrashennyh dragotsennymi obkladkami [About the Purpose of Wooden Vessels of the Early Nomads of the Southern Urals, Decorated with Precious Plates]. Yuzhnyjy Ural i sopredel'nye territorii v skifo-sarmatskoe vremya. Sbornik statey k 70-letiyu A.H. Pshenichnyuka [Southern Urals and Adjacent Territories in the ScythianSarmatian Time. Collection of Articles Dedicated to the $70^{\text {th }}$ Anniversary of A. Kh. Pshenichnyuk]. Ufa, Gilem Publ., pp. 46-57.

Yablonskiy L.T., Meshcheryakov D.V., 2007. Raskopki «tsarskogo» kurgana v Filippovke (predvaritel'noe soobshchenie) [Excavations of the "royal" Mound at Filippovka (Preliminary Publication)]. Rossiyskaya arkheologiya [Russian Archaeology], pp. 55-62.

Yablonskiy L.T., 2008. Otchet o raskopkah kurgana 4 mogil'nika Filippovka 1 na territorii Ilekskogo rajona Orenburgskoj obl. RF v 2006 g. [Report on the Excavation Kurgan 4 of the Filippovka 1 Necropolis on the Territory of the Ilekskiy District of the Orenburg Region of the Russian Federation in 2006]. Arkhiv IA RAN, no. R-1, 44152, 44153.

Yablonskiy L.T., 2013. Zoloto sarmatskih vozhdey. Elitnyy nekropol' Filippovka 1 (po materialam raskopok 2004-2009 gg.). Katalog kollektsii [Gold of the Sarmatian Leaders. The Elite Necropolis Filippovka 1 (Based on the 2004-2009 Excavations)]. Book 1. Moscow, IA RAS. 231 p.

Yablonskiy L.T., 2014. Otchet o dosledovanii kurgana 1 mogil'nika Filippovka 1 v 2013 g. [Report on the Completion of the Kurgan 1 of the Filippovka 1 Necropolis in 2013]. Arkhiv IA RAN, no. R-1. 41778, 41779.

Yablonskiy L.T., 2016. Novye arheologicheskie dannye ob ahemenidskih vliyaniyah na Yuzhnom Urale [New Archaeological Data on the Achaemenid Influence in the Southern Ural Area]. Vestnik drevney istorii [Journal of Ancient History], vol. 76, no. 3, pp. 744-766.

Yatsenko S.A., 2006. Kostyum drevney Evrazii: iranoyazychnye narody [The Costume of Ancient Eurasia: IranianSpeaking Peoples]. Moscow, Vostochnaya literatura Publ. 664 p.

\section{Information About the Authors}

Konstantin S. Okorokov, Junior Researcher, Institute of Archaeology of the Russian Academy of Sciences, Dm. Ulianova St, 19, 117292 Moscow, Russian Federation, okorokov.arx@mail.ru, https://orcid.org/0000-0001-7060-6313

Vyacheslav E. Tregubov, Senior Researcher, Orenburg Gubernatorial Museum of Local History, Sovetskaya St, 28, 46000 Orenburg, Russian Federation, v-tregubov67@mail.ru, https://orcid.org/0000-0003-2253-3441

\section{Информация об авторах}

Константин Сергеевич Окороков, младший научный сотрудник, Институт археологии РАН, ул. Дм. Ульянова, 19, 117292 г. Москва, Российская Федерация, okorokov.arx@mail.ru, https://orcid.org/0000-0001-7060-6313

Вячеслав Егорович Трегубов, старший научный сотрудник, Оренбургский губернаторский историко-краеведческий музей, ул. Советская, 28, 46000 г. Оренбург, Российская Федерация, v-tregubov67@mail.ru, https://orcid.org/0000-0003-2253-3441 